\title{
Association between ADAM metallopeptidase domain 33 gene polymorphism and risk of childhood asthma: a meta-analysis
}

\author{
F.J. Sun ${ }^{1 *}$, L.Y. Zou ${ }^{2 *}$, D.M. Tong ${ }^{3 *}$, X.Y. Lu ${ }^{1}$, J. Li $^{1}$ and C.B. Deng \\ ${ }^{1}$ Department of Pediatrics, The Fifth Affiliated Hospital of Guangzhou Medical University, Guangzhou, China \\ ${ }^{2}$ Department of Prevention and Health Care, The Third Affiliated Hospital, Sun Yat-sen University, Guangzhou, China \\ ${ }^{3}$ Department of Traditional Chinese Medicine, The Fifth Affiliated Hospital of Guangzhou Medical University, Guangzhou, China
}

\begin{abstract}
This study aimed to investigate the association between ADAM metallopeptidase domain 33 (ADAM33) gene polymorphisms and the risk of childhood asthma. The relevant studies about the relationship between ADAM33 gene polymorphisms and childhood asthma were searched from electronic databases and the deadline of retrieval was May 2016. The single nucleotide polymorphisms (SNPs) of ADAM33 (rs511898, rs2280092, rs3918396, rs528557, rs2853209, rs44707, rs2280091 and rs2280089) were analyzed based on several models including the allele, codominant, recessive and dominant models. The results showed that the ADAM33 rs2280091 polymorphism in all four genetic models was associated with an increased risk of childhood asthma. Positive associations were also found between the polymorphisms rs2280090, rs2787094, rs44707 and rs528557 and childhood asthma in some genetic models. This meta-analysis suggested that ADAM33 polymorphisms rs2280091, rs2280090, rs2787094, rs44707 and rs528557 were significantly associated with a high risk of childhood asthma.
\end{abstract}

Key words: Childhood; Asthma; ADAM33; Gene polymorphisms; Asthma risk; Meta-analysis

\section{Introduction}

Asthma is a common respiratory disorder in both adults and children, characterized by bronchial hyper-responsiveness, airway inflammation, airflow obstruction, wheezing and breathlessness. Nowadays, the prevalence of asthma in children is increasing worldwide and has become one of the major causes of child hospitalization and morbidity (1). This disease can be induced by environmental factors (such as bacterial infections and tobacco smoke) and multiple genetic factors (2-4). Commonly, asthma starts with wheezing, but in young children with dysfunctional maturating immune system, not all wheezing progresses to asthma. It has been reported that environmental factors as well as genetic predisposition play important roles in asthma development in children $(5,6)$. Several candidate genes have been reported to be functionally implicated during the occurrence and development of asthma, such as pro-inflammatory genes, anti-inflammatory genes, airway remodeling genes, immune modulation genes, etc. (7).

The ADAM (a disintegrin and metalloproteinase) family, a subgroup of the metzincin metalloproteinase superfamily, plays an important role in physiologic processes, such as cell migration, cell fusion, fertilization and immune response $(8,9)$. ADAM33 (ADAM Metallopeptidase Domain 33) is an asthma susceptible gene, and is associated with asthma and bronchial hyper-responsiveness (10). It is located on the human chromosome 20p13 and is highly polymorphic, containing over 70 single-nucleotide polymorphisms (SNPs) (11). ADAM33 is typically expressed in bronchial smooth muscle cells and human lung fibroblasts. Alterations in ADAM33 activity may influence the function of these cells, thereby resulting in airway remodeling (12). Moreover, airway obstruction and bronchial hyper-reactivity induced by the occurrence of airway remodeling are closely related to asthma (13). Recently, several ADAM33 polymorphisms have been shown to be associated with childhood asthma. For example, Shalaby et al. (14) reported that the rs511898 homozygous mutant genotype and the rs44707 heterozygous genotype of ADAM33 were significantly associated with the risk of childhood asthma. A recent cohort study reported a positive relationship of rs2243250 and rs2070874 polymorphisms with childhood asthma (7). There was no consistent opinion to

Correspondence: F.J. Sun <sybada2002@163.com> | C.B. Deng <changbaideng612@sina.com>

${ }^{*}$ These authors contributed equally to this study.

Received January 21, 2017 | Accepted April 26, 2017 
explain the effect of ADAM33 polymorphisms on asthma in children.

In this study, we performed a meta-analysis to examine the association between ADAM33 polymorphism and risk of asthma in children. This study may provide new perspectives in explaining the significance of ADAM33 for predicting the risk of childhood asthma.

\section{Material and Methods}

\section{Data source}

Related studies were searched in PubMed (http:// www.ncbi.nlm.nih.gov/pubmed/) and Embase (http://www. embase.com). Key words used for retrieving were "childhood asthma" or "pediatric asthma" or "asthma in children" and "ADAM33". The language was restricted to English. The deadline of retrieval was May 2016.

\section{Inclusion and exclusion criteria}

The included studies met the following inclusion criteria: 1) reported the relationship between ADAM33 polymorphism and risk of asthma in children; and 2) SNP distributions were available in cases and controls for evaluating odds ratio with its $95 \%$ confidence interval $(\mathrm{Cl})$. Studies were excluded if they were reviews, reports, comments, letters, etc.

\section{Data extraction}

Two investigators independently extracted the useful information using a standardized form. The following items were extracted: the name of the first author, publication year, geographical location, study year, study type, as well as the gender and age information of the participants,

Literature search in PubMed $(\mathrm{n}=46)$, Embase $(n=244)$

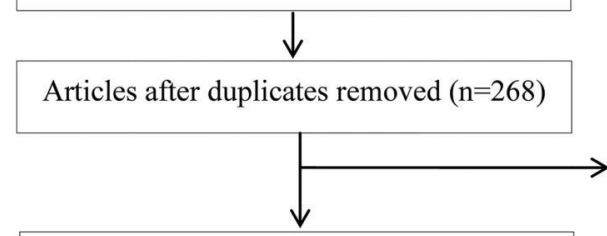

Articles excluded:

Obvious irrelevance $(n=224)$

Articles abstract reviewed $(n=44)$

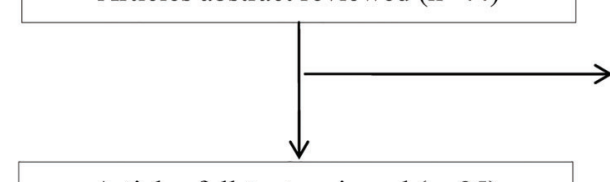

Articles full-text reviewed $(\mathrm{n}=25)$

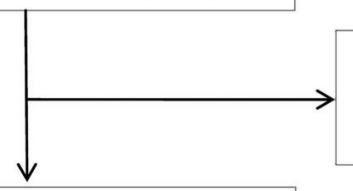

Articles excluded $(n=17)$ :

8 review; 4 cannot extract data;

5 duplicated populations. allele frequencies, and number of patients and controls in each SNP (rs511898, rs2280092, rs3918396, rs528557, rs2853209, rs44707, rs2280091 and rs2280089). Divergences were settled by discussion with another investigator.

\section{Statistical analysis}

We first examined if genotype distribution in control participants was in accordance with the Hardy-Weinberg equilibrium (HWE) in each study by Pearson's $X^{2}$ test (15). A meta-analysis was performed with the $\mathrm{R}$ statistical package, version 3.12 (https://www.r-project.org/). The association strength between children asthma risk and ADAM33 polymorphisms was estimated by odds ratios (OR) and 95\% $\mathrm{Cl}$ (16). Heterogeneity among studies was detected based on the chi-square $Q$ test and $l^{2}$ test. Heterogeneity was significant when the $P$ value was $<0.1$ or $P^{2}>50 \%$, and the random effect model was used to calculate the pooled effect. Otherwise, the fixed effect model was used (17). Publication bias was evaluated by Egger's method (18).

\section{Results}

\section{Study selection}

The flow chart of the selection progress is listed in Figure 1. Briefly, 290 articles were preliminarily identified from PubMed $(n=46)$ and Embase $(n=244)$. Of these, 22 duplicate articles were removed. After reading the titles, abstracts and whole test, if possible, another 224 articles were excluded due to obviously irrelevant data. The studies including both adult asthma and children asthma were also excluded. The abstracts of the remaining articles were carefully read, and 19 of them including 3 letters and

Figure 1. Flow chart of literature search and study selection.

Articles included for Meta-analysis $(\mathrm{n}=8)$ 
16 case series or case reports were excluded. By reading the full text of the remaining 25 articles, 17 were excluded due to duplicated populations or unavailable data. Finally, a total of 8 eligible studies were included in this metaanalysis $(7,14,19-24)$.

The included studies were published between 2008 and 2016 and were from Saudi Arabia, India, Portugal, Brazil, Czech, Netherlands, Egypt and China (Table 1). There was no significant difference in age and gender among these studies. All were observational studies, including 1 cohort study, 2 cross-sectional pilot studies and 5 case-control studies. The article by Klaassen et al. (7) was based on two types of studies, ADEM (Asthma Detection and Monitoring) study and KOALA study (the Child, Parent and Health: Lifestyle and, Genetic Constitution study). Therefore, the information of these two types of studies were extracted and listed independently in the Tables.

The SNPs of ADAM33 including rs511898, rs2280092, rs3918396, rs528557, rs2853209, rs44707, rs2280091 and rs2280089 were analyzed in this meta-analysis. Distributions of these genotypes in control and in asthmatic children are listed in Table 2. Genotype distributions of almost all of the control populations were consistent with the HWE.

\section{Meta-analysis}

The results regarding the associations between polymorphisms of ADAM33 and asthma risk of children are listed in Table 3 and Supplementary Figures S1-S5. Four genetic models were analyzed for each ADAM33 polymorphism: allele model (wild vs mutation), codominant model (heterozygote vs wild homozygote, mutational homozygote vs wild homozygote), recessive model (wild homozygote vs heterozygote + wild homozygote), and dominant model (wild homozygote + heterozygote vs wild homozygote).

Heterogeneity test was performed for the selection of a suitable model for pooled effect. The meta-analysis results indicated that all the four models of rs2280091 increased the risk of childhood asthma. In the allele model, the rs2280090, rs2280091 and rs44707 polymorphisms increased the risk of childhood asthma, with OR of 1.42 (1.09-1.85), 2.06 (1.45-2.92) and 1.48 (1.25$1.75)$ respectively. In the codominant model of heterozygote vs wild homozygote, the associations between rs2280091 and rs528557 polymorphisms and asthma in children were significant $(\mathrm{OR}=1.91,95 \% \mathrm{Cl}=1.24-2.94$, and $\mathrm{OR}=2.92,95 \% \mathrm{Cl}=1.33-6.39$, respectively). In the codominant model of mutational homozygote vs wild homozygote, significant results were found in 3 polymorphisms: rs2280091 (OR=4.48, 95\% Cl=2.93-6.84), rs2787094 $(\mathrm{OR}=2.12,95 \% \mathrm{Cl}=1.01-4.48)$, and $\mathrm{rs} 44707$ $(\mathrm{OR}=2.16,95 \% \mathrm{Cl}=1.52-3.07)$. In the recessive model, the $\mathrm{rs} 2280090(\mathrm{OR}=1.50,95 \% \mathrm{Cl}=1.11-2.02)$, rs2280091 $(\mathrm{OR}=2.65,95 \% \mathrm{Cl}=2.08-3.38)$ and $\mathrm{rs} 44707 \quad(\mathrm{OR}=1.68$,

Table 1. Characteristics of the included studies.

\begin{tabular}{|c|c|c|c|c|c|c|c|}
\hline \multirow{2}{*}{$\begin{array}{l}\text { Author } \\
\text { (reference, year) }\end{array}$} & \multirow{2}{*}{$\begin{array}{l}\text { Study } \\
\text { location }\end{array}$} & \multirow[t]{2}{*}{ Study year } & \multicolumn{2}{|c|}{ Gender (M/F) } & \multicolumn{2}{|c|}{ Age (years) } & \multirow[t]{2}{*}{ Study design } \\
\hline & & & Asthma & Control & Asthma & Control & \\
\hline $\begin{array}{l}\text { Al-Khayyat Al } \\
\text { (19) } 2012\end{array}$ & Saudi Arabia & NA & $70 / 37$ & NA & $3-12$ & $3-12$ & $\begin{array}{l}\text { Cross-sectional } \\
\text { pilot study }\end{array}$ \\
\hline $\begin{array}{l}\text { Awasthi S } \\
\text { (20) } 2011\end{array}$ & India & 2007 to 2009 & $143 / 68$ & $96 / 41$ & $\begin{array}{c}74.39 \pm 45.76 \\
\text { months }\end{array}$ & $\begin{array}{c}73.61 \pm 42.56 \\
\text { months }\end{array}$ & $\begin{array}{l}\text { Case-control } \\
\text { study }\end{array}$ \\
\hline $\begin{array}{l}\text { Berenguer AG } \\
\text { (21) } 2014\end{array}$ & Portugal & NA & $58 / 40$ & NA & $13.6 \pm 4.3$ & NA & $\begin{array}{l}\text { Case-control } \\
\text { study }\end{array}$ \\
\hline $\begin{array}{l}\text { de Faria ICJ } \\
\text { (22) } 2008\end{array}$ & Brazil & 2006 to 2007 & NA & NA & NA & NA & $\begin{array}{l}\text { Case-control } \\
\text { study }\end{array}$ \\
\hline $\begin{array}{l}\text { Godava M } \\
\text { (23) } 2012\end{array}$ & Czech & 2003 to 2005 & $76 / 35$ & NA & $0.4-20$ & NA & $\begin{array}{l}\text { Cross-sectional } \\
\text { pilot study }\end{array}$ \\
\hline $\begin{array}{l}\text { Klaassen EM1 } \\
\text { (7) } 2015\end{array}$ & Netherlands & NA & $46 / 30$ & $63 / 59$ & $6.0 \pm 0.1$ & $6.0 \pm 0.1$ & Cohort study \\
\hline $\begin{array}{l}\text { Klaassen EM2 } \\
\text { (7) } 2015\end{array}$ & Netherlands & NA & $37 / 20$ & $108 / 83$ & $6.5 \pm 0.5$ & $6.5 \pm 0.6$ & Cohort study \\
\hline $\begin{array}{l}\text { Qu SQ } \\
\text { (24) } 2011\end{array}$ & China & NA & $199 / 213$ & $192 / 205$ & $7.74 \pm 2.78$ & $7.52 \pm 2.95$ & $\begin{array}{l}\text { Case-control } \\
\text { study }\end{array}$ \\
\hline $\begin{array}{l}\text { Shalaby SM } \\
\text { (14) } 2016\end{array}$ & Egypt & NA & $215 / 185$ & $102 / 98$ & $8.5 \pm 3.6$ & $8.8 \pm 2.6$ & $\begin{array}{l}\text { Case-control } \\
\text { study }\end{array}$ \\
\hline
\end{tabular}

Klaassen EM1: data from the study reported by Klaassen based on ADEM (Asthma Detection and Monitoring) study; Klaassen EM2: data from the study reported by Klaassen based on KOALA study (the Child, Parent and Health: Lifestyle and, Genetic Constitution study); NA: not available. 
Table 2. Distribution of ADAM33 polymorphisms.

\begin{tabular}{|c|c|c|c|c|c|c|c|c|c|c|c|c|}
\hline \multirow{2}{*}{$\begin{array}{l}\text { Conventional marking } \\
\text { (reference) }\end{array}$} & \multirow[t]{2}{*}{ SNP } & \multirow[t]{2}{*}{ Wild type } & \multicolumn{4}{|c|}{ Asthma } & \multicolumn{4}{|c|}{ Control } & \multirow[t]{2}{*}{$x^{2 *}$} & \multirow[t]{2}{*}{$\mathrm{P}$} \\
\hline & & & $\mathrm{n}$ & $\mathrm{WH}$ & $\mathrm{HT}$ & $\mathrm{MH}$ & $\mathrm{n}$ & $\mathrm{WH}$ & $\mathrm{HT}$ & $\mathrm{MH}$ & & \\
\hline \multicolumn{13}{|l|}{ Al-Khayyat Al (19) } \\
\hline $\mathrm{T} 1(\mathrm{~T}>\mathrm{C})$ & rs2280091 & $\mathrm{T}$ & 96 & 38 & 47 & 11 & 86 & 53 & 28 & 5 & 0.245 & 0.6204 \\
\hline $\mathrm{T} 2(\mathrm{G}>\mathrm{A})$ & rs2280090 & G & 94 & 41 & 46 & 7 & 84 & 52 & 25 & 7 & 2.144 & 0.1431 \\
\hline $\mathrm{ST}+4(\mathrm{~A}>\mathrm{C})$ & rs44707 & $A$ & 99 & 48 & 46 & 5 & 60 & 32 & 28 & 0 & 5.558 & 0.0184 \\
\hline $\mathrm{S} 1(\mathrm{C}>\mathrm{T})$ & rs3918396 & $\mathrm{C}$ & 96 & 90 & 6 & 0 & 82 & 80 & 2 & 0 & 0.012 & 0.9110 \\
\hline \multicolumn{13}{|l|}{ Awasthi S (20) } \\
\hline$F+1(G>A)$ & rs511898 & G & 211 & 39 & 94 & 78 & 137 & 40 & 73 & 24 & 0.889 & 0.3458 \\
\hline V4 $(C>G)$ & rs2787094 & $\mathrm{C}$ & 211 & 34 & 90 & 87 & 137 & 33 & 58 & 46 & 2.910 & 0.0880 \\
\hline $\mathrm{ST}+4(\mathrm{~A}>\mathrm{C})$ & rs44707 & $A$ & 211 & 38 & 94 & 79 & 137 & 37 & 59 & 41 & 2.615 & 0.1058 \\
\hline$S 2(C>G)$ & rs528557 & $\mathrm{C}$ & 211 & 18 & 85 & 108 & 137 & 72 & 51 & 14 & 1.156 & 0.2824 \\
\hline $\mathrm{ST}+5(\mathrm{C}>\mathrm{T})$ & Rs597980 & C & 211 & 26 & 94 & 91 & 137 & 33 & 67 & 37 & 0.061 & 0.8053 \\
\hline \multicolumn{13}{|l|}{ Berenguer AG (21) } \\
\hline $\mathrm{V} 4(\mathrm{C}>\mathrm{G})$ & rs2787094 & $\mathrm{C}$ & 98 & 74 & 23 & 1 & 105 & 80 & 22 & 3 & 0.815 & 0.3667 \\
\hline$S 1(G>A)$ & rs3918396 & $\mathrm{G}$ & 98 & 91 & 7 & 0 & 105 & 95 & 10 & 0 & 0.263 & 0.6084 \\
\hline \multicolumn{13}{|l|}{ de Faria ICJ (22) } \\
\hline$S 2(C>G)$ & rs528557 & $\mathrm{C}$ & 88 & 11 & 38 & 39 & 202 & 11 & 136 & 55 & 37.466 & $<0.001$ \\
\hline \multicolumn{13}{|l|}{ Godava M (23) } \\
\hline$F+1(G>A)$ & rs511898 & $\mathrm{G}$ & 109 & 32 & 58 & 19 & 45 & 15 & 22 & 8 & $<0.001$ & 0.9892 \\
\hline$L-1(G>A)$ & rs2280092 & $G$ & 109 & 69 & 37 & 3 & 45 & 31 & 12 & 2 & 0.324 & 0.5694 \\
\hline$S 1(G>A)$ & rs3918396 & $G$ & 109 & 94 & 15 & 0 & 45 & 36 & 8 & 1 & 0.384 & 0.5353 \\
\hline$S 2(C>G)$ & rs528557 & C & 109 & 49 & 46 & 14 & 45 & 21 & 18 & 6 & 0.444 & 0.5052 \\
\hline$S+1(A>T)$ & rs2853209 & $A$ & 109 & 40 & 49 & 20 & 45 & 14 & 22 & 9 & 0.004 & 0.9465 \\
\hline $\mathrm{ST}+4(\mathrm{~T}>\mathrm{C})$ & rs44707 & $\mathrm{T}$ & 109 & 42 & 51 & 16 & 45 & 19 & 19 & 7 & 0.060 & 0.9703 \\
\hline $\mathrm{T} 1(\mathrm{~T}>\mathrm{C})$ & rs2280091 & $\mathrm{T}$ & 109 & 66 & 38 & 5 & 45 & 31 & 12 & 2 & 0.324 & 0.5694 \\
\hline $\mathrm{T}+1(\mathrm{C}>\mathrm{T})$ & rs2280089 & $\mathrm{C}$ & 109 & 68 & 39 & 3 & 45 & 27 & 16 & 2 & 0.037 & 0.8467 \\
\hline$V-3(G>A)$ & rs628977 & G & 109 & 79 & 27 & 3 & 45 & 34 & 9 & 2 & 1.370 & 0.2418 \\
\hline $\mathrm{V} 4(\mathrm{C}>\mathrm{G})$ & rs2787094 & $\mathrm{C}$ & 109 & 65 & 41 & 3 & 45 & 27 & 17 & 1 & 0.914 & 0.3390 \\
\hline$V 5(A>G)$ & rs13527 & $A$ & 109 & 95 & 13 & 1 & 45 & 41 & 4 & 0 & 0.097 & 1.0000 \\
\hline \multicolumn{13}{|l|}{ Klaassen EM1 (7) } \\
\hline$F+1(G>A)$ & rs511898 & G & 75 & 32 & 38 & 5 & 121 & 40 & 60 & 21 & 0.034 & 0.8533 \\
\hline$S 2(C>G)$ & rs528557 & $\mathrm{C}$ & 76 & 41 & 35 & 0 & 122 & 49 & 73 & 0 & 3.588 & 0.058 \\
\hline \multicolumn{13}{|l|}{ Klaassen EM2 (7) } \\
\hline$F+1(G>A)$ & rs511898 & G & 56 & 26 & 21 & 9 & 169 & 76 & 91 & 2 & 23.476 & $<0.001$ \\
\hline$S 2(C>G)$ & rs528557 & $\mathrm{C}$ & 55 & 35 & 20 & 0 & 176 & 94 & 82 & 0 & 1.778 & 0.182 \\
\hline \multicolumn{13}{|l|}{ Qu SQ (24) } \\
\hline$F+1(G>A)$ & rs511898 & G & 412 & 178 & 198 & 36 & 397 & 173 & 182 & 42 & 0.333 & 0.5637 \\
\hline$T+1(C>T)$ & rs2280089 & $\mathrm{C}$ & 412 & 301 & 97 & 14 & 397 & 355 & 39 & 3 & 1.980 & 0.1594 \\
\hline $\mathrm{T} 2(\mathrm{G}>\mathrm{A})$ & rs2280090 & G & 412 & 319 & 86 & 7 & 397 & 326 & 69 & 2 & 0.756 & 0.3844 \\
\hline $\mathrm{T} 1(\mathrm{~T}>\mathrm{C})$ & rs2280091 & $\mathrm{T}$ & 412 & 140 & 185 & 87 & 397 & 240 & 129 & 28 & 3.147 & 0.0761 \\
\hline $\mathrm{V} 4(\mathrm{C}>\mathrm{G})$ & rs2787094 & C & 412 & 141 & 198 & 73 & 397 & 232 & 134 & 31 & 3.259 & 0.0710 \\
\hline$Q-1(G>A)$ & rs612709 & $\mathrm{G}$ & 412 & 305 & 100 & 7 & 397 & 307 & 87 & 3 & 1.620 & 0.2031 \\
\hline \multicolumn{13}{|l|}{ Shalaby SM (14) } \\
\hline$F+1(G>A)$ & rs511898 & G & 400 & 77 & 178 & 145 & 200 & 58 & 107 & 35 & 1.427 & 0.2323 \\
\hline $\mathrm{ST}+4(\mathrm{~A}>\mathrm{C})$ & rs44707 & A & 400 & 109 & 195 & 96 & 200 & 87 & 84 & 29 & 1.362 & 0.2431 \\
\hline
\end{tabular}

SNP: single nucleotide polymorphism; WH: wild homozygote; HT: heterozygote; MH: mutational homozygote; NOS: Newcastle-Ottawa Scale; $n$ : total number of including subjects. *likelihood-ratio $\mathrm{X}^{2}$.

$95 \% \mathrm{Cl}=1.31-2.16)$ also showed an association with high risk of childhood asthma. In the dominant model, four polymorphisms increased the risk of asthma in children: rs2280091
$(\mathrm{OR}=3.08,95 \% \mathrm{Cl}=2.06-4.61), \quad \mathrm{rs} 2787094 \quad(\mathrm{OR}=1.81$, $95 \% \mathrm{Cl}=1.34-2.46), \mathrm{rs} 44707(\mathrm{OR}=1.59,95 \% \mathrm{Cl}=1.17-2.15)$ and $\mathrm{rs} 528557(\mathrm{OR}=3.30,95 \% \mathrm{Cl}=1.09-10.02)$. 
Table 3. Meta-analysis results of association between ADAM33 and childhood asthma.

\begin{tabular}{|c|c|c|c|c|c|c|c|}
\hline \multirow[t]{2}{*}{ SNP } & \multicolumn{2}{|c|}{$\mathrm{K}$} & \multirow{2}{*}{$\begin{array}{l}\text { Test of association } \\
\text { OR }(95 \% \mathrm{Cl})\end{array}$} & \multirow[t]{2}{*}{ Model } & \multicolumn{3}{|c|}{ Test of heterogeneity ${ }^{a, b}$} \\
\hline & Cases & Control & & & $Q$ & $P$ & $l^{2}(\%)$ \\
\hline \multicolumn{8}{|l|}{ Allele model } \\
\hline rs2280089 & 1044 & 884 & $1.68[0.52-5.42]$ & Random & 11.44 & 0.0007 & 91.30 \\
\hline rs2280090 & 1012 & 962 & 1.42 [1.09-1.85] & Fixed & 0.19 & 0.6594 & 0 \\
\hline rs2280091 & 1234 & 1056 & $2.06[1.45-2.92]$ & Random & 4.35 & 0.1134 & 54.10 \\
\hline rs2787094 & 1660 & 1368 & $1.40[0.93-2.10]$ & Random & 13.71 & 0.0033 & 78.10 \\
\hline rs3918396 & 606 & 464 & $0.82[0.46-1.47]$ & Fixed & 2.6 & 0.2722 & 23.20 \\
\hline rs44707 & 1638 & 884 & $1.48[1.25-1.75]$ & Fixed & 3.25 & 0.355 & 7.60 \\
\hline rs511898 & 2526 & 2138 & 1.22 [0.88-1.68] & Random & 29.64 & $<0.0001$ & 83.10 \\
\hline rs528557 & 816 & 728 & $2.13[0.70-6.48]$ & Random & 46.01 & $<0.0001$ & 95.70 \\
\hline \multicolumn{8}{|c|}{ Codominant model 1} \\
\hline rs2280089 & 153 & 60 & 1.36 [0.48-3.88] & Fixed & 0.92 & 0.3379 & 0 \\
\hline rs2280090 & 146 & 103 & $1.03[0.43-2.51]$ & Fixed & 2.68 & 0.1014 & 62.7 \\
\hline rs2280091 & 373 & 204 & $1.91[1.24-2.94]$ & Fixed & 1.64 & 0.4415 & 0 \\
\hline rs2787094 & 516 & 312 & 1.35 [0.97-1.88] & Fixed & 2.11 & 0.5499 & 0 \\
\hline rs44707 & 582 & 267 & $1.31[0.95-1.81]$ & Fixed & 2.08 & 0.5554 & 0 \\
\hline rs511898 & 879 & 667 & $1.59[0.77-3.30]$ & Random & 32.52 & $<0.001$ & 84.6 \\
\hline rs528557 & 330 & 260 & 2.92 [1.33-6.39] & Random & 6.61 & 0.0366 & 69.8 \\
\hline \multicolumn{8}{|c|}{ Codominant model 2} \\
\hline rs2280089 & 386 & 387 & $2.01[0.23-17.8]$ & Random & 3.86 & 0.0495 & 74.1 \\
\hline rs2280090 & 374 & 387 & $1.89[0.78-4.57]$ & Fixed & 1.11 & 0.2924 & 9.8 \\
\hline rs2280091 & 347 & 359 & $4.48[2.93-6.84]$ & Fixed & 3.34 & 0.1885 & 40.1 \\
\hline rs2787094 & 478 & 453 & $2.12[1.07-4.48]$ & Random & 7.29 & 0.0631 & 58.9 \\
\hline rs44707 & 433 & 252 & $2.16[1.52-3.07]$ & Fixed & 3.44 & 0.3287 & 12.8 \\
\hline rs511898 & 676 & 534 & $1.71[0.76-3.85]$ & Random & 34.98 & $<0.0001$ & 85.7 \\
\hline rs528557 & 239 & 159 & $3.32[0.30-36.16]$ & Random & 40.06 & $<0.0001$ & 95 \\
\hline \multicolumn{8}{|c|}{ Recessive model } \\
\hline rs2280089 & 522 & 442 & $1.77[0.54-5.78]$ & Random & 8.66 & 0.0033 & 88.4 \\
\hline rs2280090 & 506 & 481 & $1.50[1.11-2.02]$ & Fixed & 1.63 & 0.2021 & 38.5 \\
\hline rs2280091 & 617 & 528 & $2.65[2.08-3.38]$ & Fixed & 3.28 & 0.1944 & 38.9 \\
\hline rs2787094 & 830 & 684 & $1.56[0.93-2.64]$ & Random & 12.28 & 0.0065 & 75.6 \\
\hline rs3918396 & 303 & 232 & $0.86[0.47-1.59]$ & Fixed & 2.37 & 0.3059 & 15.6 \\
\hline rs44707 & 819 & 442 & $1.68[1.31-2.16]$ & Fixed & 3.24 & 0.3556 & 7.5 \\
\hline rs511898 & 1263 & 1069 & $1.18[0.88-1.59]$ & Random & 11.51 & 0.0422 & 56.5 \\
\hline rs528557 & 539 & 662 & $1.18[0.34-4.14]$ & Random & 73.05 & $<0.0001$ & 94.5 \\
\hline \multicolumn{8}{|c|}{ Dominant model } \\
\hline rs2280089 & 532 & 442 & 1.86 [0.25-13.73] & Random & 3.29 & 0.0695 & 69.6 \\
\hline rs2280090 & 506 & 481 & $1.46[0.62-3.44]$ & Fixed & 1.92 & 0.1658 & 47.9 \\
\hline rs2280091 & 617 & 528 & $3.09[2.06-4.61]$ & Fixed & 2.44 & 0.2947 & 18.2 \\
\hline rs2787094 & 830 & 684 & $1.81[1.34-2.46]$ & Fixed & 5.68 & 0.1284 & 47.2 \\
\hline rs44707 & 819 & 442 & 1.59 [1.17-2.15] & Fixed & 2.92 & 0.4043 & 0 \\
\hline rs511898 & 1263 & 1069 & 1.62 [0.78-3.37] & Random & 36.34 & $<0.0001$ & 86.2 \\
\hline rs528557 & 408 & 364 & 3.30 [1.09-10.02] & Random & 14.97 & 0.0006 & 86.6 \\
\hline
\end{tabular}

OR: odds ratio; Cl: confidence interval; Codominant model 1: heterozygote vs wild homozygote; Codominant model 2: mutational homozygote vs wild homozygote. ${ }^{a}$ Random-effects model was used when the $P$ value for heterogeneity test was $<0.01$, otherwise the fixedeffect model was used. ${ }^{b} \mathrm{P}<0.10$ was considered to be statistically significant for $\mathrm{Q}$ statistics.

\section{Discussion}

The present meta-analysis evaluated the relationship between ADAM33 polymorphisms and asthma risk in children. Results showed that in all four genetic models of ADAM33, the rs2280091 polymorphism was associated with the increased risk of childhood asthma. Positive associations were also found between the polymorphisms 
rs2280090 (allele model and recessive model), rs2787094 (codominant model 2 and dominant model), rs44707 (allele model, codominant model 2, recessive model and dominant model) and rs528557 (codominant model 1 and dominant model) and childhood asthma. These data suggest that these ADAM33 polymorphisms may be causative factors for asthma in children.

ADAM33 was first regarded as a susceptibility gene for bronchial hyper-responsiveness and asthma by a genome-wide linage analysis (25). More than 70 SNPs have been identified in this gene. Some of the asthmarelated SNPs are located in regions encoding amino acid changes (26). Others are non-coding SNPs but affect the viability of smooth muscle cells and fibroblasts, affect the inflammation of the airways, and affect the association with other SNPs (26). Therefore, ADAM33 genetic variations may lead to abnormal changes of smooth muscle cells and fibroblasts, thus result in hyper-responsiveness and remodeling of the airway, which is correlated with development of inflammation (13). In a previous meta-analysis, Zheng et al. (27) reported that the ADAM33 rs2280091 polymorphism increased the risk of asthma. The replication of the positive association confirmed the effect of rs2280091 on asthma. However, the meta-analysis by Zheng et al. (27) only illustrated the relationship of one SNP in adults. In the present study, other polymorphisms such as rs2280090, rs2787094, rs44707 and rs528557 were also found to be related to the increased risk of childhood asthma. Although the function of these SNPs in the development of asthma is not fully understood, it is likely that the ADAM33 is an important chemokine in gene mutations that affects the pathogenesis of asthma in children.

Just as other meta-analyses, heterogeneity was found among the articles. The included studies were

\section{References}

1. Maziak W, Behrens $T$, Brasky $T$, Duhme $H$, Rzehak $P$, Weiland $S$, et al. Are asthma and allergies in children and adolescents increasing? Results from ISAAC phase I and phase III surveys in Münster, Germany. Allergy 2003; 58: 572-579, doi: 10.1034/j.1398-9995.2003.00161.x.

2. Holgate $S$, Davies D, Powell R, Howarth $P$, Haitchi $H$, Holloway J. Local genetic and environmental factors in asthma disease pathogenesis: chronicity and persistence mechanisms. Eur Respir J 2007; 29: 793-803, doi: 10.1183/ 09031936.00087506

3. Chang J-C, Wang L, Chen R-F, Liu C-A. Perinatal genegene and gene-environment interactions on IgE production and asthma development. Clin Dev Immunol 2012; 2012: 270869, doi: 10.1155/2012/270869.

4. Bottema RW, Kerkhof M, Reijmerink NE, Thijs C, Smit HA, van Schayck $C P$, et al. Gene-gene interaction in regulatory T-cell function in atopy and asthma development in childhood. J Allergy Clin Immunol 2010; 126: 338-346. e310, doi: 10.1016/j.jaci.2010.04.024. from different geographical regions, including Asia (Saudi Arabia, India and China), Europe (Portugal, Czech and Netherlands), Africa (Egypt) and America (Brazil), which might contribute to the heterogeneity of genetic diversity. Besides, children in different countries received different medical care, which also influences the phenotype of asthma, and thus might lead to heterogeneity.

Several limitations in this meta-analysis should be pointed out when explaining our results. First, though there might be some confounding factors that affect the results of this meta-analysis, we did not perform subgroup analysis because of insufficient data. Second, only studies selected from databases were included, and thus publication bias might exist. We did not perform the publication bias analysis because eligible studies were less than 10. Third, the control group of some included studies were not ideal since a slight deviation from HWE was found. Therefore, more keywords should be used to retrieve more studies for further evaluate the relationship between ADAM33 polymorphism and childhood asthma.

In conclusion, ADAM33 polymorphisms rs2280091, rs2280090, rs2787094, rs44707 and rs528557 were significantly associated with a high risk of childhood asthma.

\section{Supplementary material}

Click here to view [pdf].

\section{Acknowledgments}

This study was supported by The Medicine and Health Care Technology General Lead Project of Guangzhou (No. 20151A011094 and 20161A011091).

5. Chang JC, Wang L, Chen RF, Liu CA. Perinatal gene-gene and gene-environment interactions on IgE production and asthma development. Clin Dev Immunol 2012; 2012: 270869, doi: $10.1155 / 2012 / 270869$.

6. Bottema RWB, Kerkhof M, Reijmerink NE, Thijs C, Smit HA, Schayck CPV, et al. Gene-gene interaction in regulatory T-cell function in atopy and asthma development in childhood. J Allergy Clin Immunol 2010; 126: 338-346, doi: 10.1016/ j.jaci.2010.04.024.

7. Klaassen EM, Penders J, Jöbsis Q, Kd VDK, Thijs C, Mommers $\mathrm{M}$, et al. An ADAM33 polymorphism associates with progression of preschool wheeze into childhood asthma: a prospective case-control study with replication in a birth cohort study. Plos One 2015; 10: e0119349, doi: 10.1371/ journal.pone.0119349.

8. Huovila A-PJ, Turner AJ, Pelto-Huikko M, Kärkkäinen I, Ortiz RM. Shedding light on ADAM metalloproteinases. Trends Biochem Sci 2005; 30: 413-422, doi: 10.1016/j.tibs.2005. 05.006 . 
9. Yamamoto S, Higuchi Y, Yoshiyama K, Shimizu E, Kataoka $\mathrm{M}$, Hijiya $\mathrm{N}$, et al. ADAM family proteins in the immune system. Immunol Today 1999; 20: 278-284, doi: 10.1016/ S0167-5699(99)01464-4.

10. Van Eerdewegh P, Little RD, Dupuis J, Del Mastro RG, Falls $\mathrm{K}$, Simon J, et al. Association of the ADAM33 gene with asthma and bronchial hyperresponsiveness. Nature 2002; 418: 426-430, doi: 10.1038/nature00878.

11. Ito I, Laporte JD, Fiset PO, Asai K, Yamauchi Y, Martin JG, et al. Downregulation of a disintegrin and metalloproteinase 33 by IFN- $\gamma$ in human airway smooth muscle cells. J Allergy Clin Immunol 2007; 119: 89-97, doi: 10.1016/j.jaci.2006. 08.038.

12. Holgate ST, Davies DE, Powell RM, Holloway JW. ADAM33: a newly identified protease involved in airway remodelling. Pulm Pharmacol Ther 2006; 19: 3-11, doi: 10.1016/j.pupt. 2005.02.008.

13. Lambrecht $B N$, Hammad $H$. The airway epithelium in asthma. Nature Med 2012; 18: 684-692, doi: 10.1038/nm. 2737.

14. Shalaby SM, Abdul-Maksoud RS, Abdelsalam SM, Abdelrahman HM, Almalky MAA. ADAM33 and ADAM12 genetic polymorphisms and their expression in Egyptian children with asthma. Ann Allergy Asthma Immunol 2015; 116: 31-36, doi: 10.1016/j.anai.2015.10.013.

15. Schaid DJ, Jacobsen SJ. Biased tests of association: comparisons of allele frequencies when departing from Hardy-Weinberg proportions. Am J Epidemiol 1999; 149: 706-711, doi: 10.1093/oxfordjournals.aje.a009878.

16. Liu T, Xu QE, Zhang $\mathrm{CH}$, Zhang P. Occupational exposure to methylene chloride and risk of cancer: a meta-analysis. Cancer Causes Control 2013; 24: 2037-2049, doi: 10.1007/ s10552-013-0283-0.

17. Feng RN, Zhao C, Sun CH, Li Y. Meta-analysis of TNF 308 G/A polymorphism and type 2 diabetes mellitus. Plos One 2012; 6: e18480, doi: 10.1371/journal.pone.0018480.

18. Egger $M$, Minder $C$. Bias in meta-analysis detected by a simple, graphical test. BMJ 1997; 315: 629-634, doi: 10.1136/ bmj.315.7109.629.
19. Al-Khayyat Al, Al-Anazi M, Warsy A, Vazquez-Tello A, Alamri AM, Halwani R, et al. T1 and T2 ADAM33 single nucleotide polymorphisms and the risk of childhood asthma in a Saudi Arabian population: a pilot study. Ann Saudi Med 2012; 32: 479-486, doi: 10.5144/0256-4947.2012.479.

20. Awasthi S, Tripathi P, Ganesh S, Husain N. Association of ADAM33 gene polymorphisms with asthma in Indian children. J Hum Genet 2011; 56: 188-195, doi: 10.1038/jhg.2010.157.

21. Berenguer AG, Fernandes AT, Oliveira $S$, Rodrigues $M$, Ornelas P, Romeira D, et al. Genetic polymorphisms and asthma: findings from a case-control study in the Madeira island population. Biol Res 2014; 47: 1-11, doi: 10.1186/ 0717-6287-47-40.

22. de Faria IC, de Faria EJ, Toro AA, Ribeiro JD, Bertuzzo CS. Association of TGF-beta1, CD14, IL-4, IL-4R and ADAM33 gene polymorphisms with asthma severity in children and adolescents. J Pediatr 2008; 84: 203-210.

23. Godava M, Kopriva F, Bohmova J, Vodicka R, Dusek L, Cvanova M, et al. Association of STAT6 and ADAM33 single nucleotide polymorphisms with asthma bronchiale and IgE level and its possible epigenetic background. Biomed Pap Med Fac Univ Palacky Olomouc Czech Repub 2012; 156: 236-247, doi: 10.5507/bp.2012.009.

24. Qu S, Sun D, Wang Y, Zhang C, Lv Y, Yao L. Association of ADAM33 polymorphisms with childhood asthma in a northern Chinese population. Exper Mol Pathol 2011; 91: 775779, doi: 10.1016/j.yexmp.2011.09.001.

25. Van EP, Little RD, Dupuis J, Del Mastro RG, Falls K, Simon $\mathrm{J}$, et al. Association of the ADAM33 gene with asthma and bronchial hyperresponsiveness. Nature 2002; 418: 426430, doi: $10.1038 /$ nature 00878 .

26. Haitchi HM, Powell RM, Shaw TJ, Howarth PH, Wilson SJ, Wilson DI, et al. ADAM33 expression in asthmatic airways and human embryonic lungs. Am J Respir Crit Care Med. 2005; 171: 958-965, doi: 10.1164/rccm.200409-12510C.

27. Zheng W, Wang L, Su X, Hu XF. Association between V4 polymorphism in the ADAM33 gene and asthma risk: a meta-analysis. Genet Mol Res 2015; 14: 989-999, doi: 10.4238/2015.February.6.2. 